\title{
A protein having similarity with methylmalonyl-CoA mutase is required for the assimilation of methanol and ethanol by Methylobacterium extorquens AM1
}

\author{
Loraine M. Smith, ${ }^{1,2}$ Wim G. Meijer, ${ }^{2}$ Lubbert Dijkhuizen ${ }^{2}$ \\ and Pat M. Goodwin' $\dagger$
}

Author for correspondence: Pat M. Goodwin. Tel: +44171 6118690 . Fax: +44 1716118363.
e-mail: p.goodwin@wellcome.ac.uk

1 School of Cell and Molecular Biology, NESCOT, Reigate Road, Epsom KT17 3DS, UK

2 Department of Microbiology, Groningen Biomolecular Sciences and Biotechnology Institute (GBB), University of Groningen, Kerklaan 30 9751 NN Haren, The Netherlands

\begin{abstract}
A $4.0 \mathrm{~kb}$ region of Methylobacterium extorquens AM1 DNA which complements three mutants unable to convert acetyl-CoA to glyoxylate (and therefore defective in the assimilation of methanol and ethanol) has been isolated and sequenced. It contains two ORFs and the 3 '-end of a third one. The mutations in all three mutants mapped within the first ORF, which was designated meaA; it encodes a protein having similarity with methylmalonylCoA mutase. However, methylmalonyl-CoA mutase was measured in extracts of one of the mutants and the specific activity was found to be similar to that in extracts of wild-type cells. Furthermore, although the predicted meaA gene product has the proposed cobalamin-binding site, it does not contain a highly conserved sequence (RIARNT) which is present in all known methylmalonylCoA mutases; meaA may therefore encode a novel vitamin- $B_{12}$-dependent enzyme. The predicted polypeptide encoded by the second ORF did not have similarity with any known proteins. The partial ORF encoded a protein with similarity with the 3-oxoacyl-[acyl-carrier-protein] reductases; it was not essential for growth on methanol or ethanol.
\end{abstract}

Keywords: Metbylobacterium, methanol, mutase, serine pathway, $\mathrm{C}_{1}$ assimilation

\section{INTRODUCTION}

Metbylobacterium extorquens AM1 is a pink-pigmented facultative methylotroph which assimilates $\mathrm{C}_{1}$ compounds by the serine pathway (Fig. 1) (Anthony, 1982). The first step in this pathway involves the condensation of a $\mathrm{C}_{1}$ tetrahydrofolate derivative with glycine to form serine, catalysed by serine hydroxymethyltransferase. The serine is then converted to $\mathrm{C}_{3}$ and $\mathrm{C}_{4}$ carboxylic acids which can be assimilated into cell material. This involves four key enzymes - serine glyoxylate aminotransferase, hydroxypyruvate reductase, glycerate kinase and an acetyl-CoAindependent phosphoenolpyruvate carboxylase. There must also be a means of regenerating the $C_{1}$ acceptor, glycine. Its immediate precursor is glyoxylate and acetate is an intermediate in the recycling pathway. In the so-

†Present address: The Wellcome Trust, 183 Euston Road, London NW1 2BE, UK.

The GenBank accession number for the nucleotide sequence reported in this paper is U28335. called $\mathrm{Icl}^{+}$serine pathway organisms, malate thiokinase, malyl-CoA lyase, isocitrate lyase and some of the tricarboxylic acid cycle enzymes are required for the conversion of acetate to glyoxylate (Bellion \& Hersh, 1972).

In $M$. extorquens AM1 there is evidence that malyl-CoA lyase and malate thiokinase are essential for the assimilation of $\mathrm{C}_{1}$ compounds (Salem et al., 1973a, 1974; Chistoserdova \& Lidstrom, 1994b). However, isocitrate lyase has never been detected in this organism, nor in a number of other serine pathway methylotrophs (Dunstan et al., 1972a ; Kortstee, 1981); such organisms are known as $\mathrm{Icl}^{-}$serine pathway methylotrophs. Although several different routes for the conversion of acetate to glyoxylate in these organisms have been proposed (Dunstan et al., 1972b; Kortstee, 1981; Shimizu et al., 1984), none of them have been confirmed. Several mutants have been described which are unable to grow on $C_{1}$ compounds unless the medium is supplemented with glyoxylate, but the biochemical basis of this phenotype has not been elucidated (Dunstan et al., 1972b; Salem et al., 1973b; 


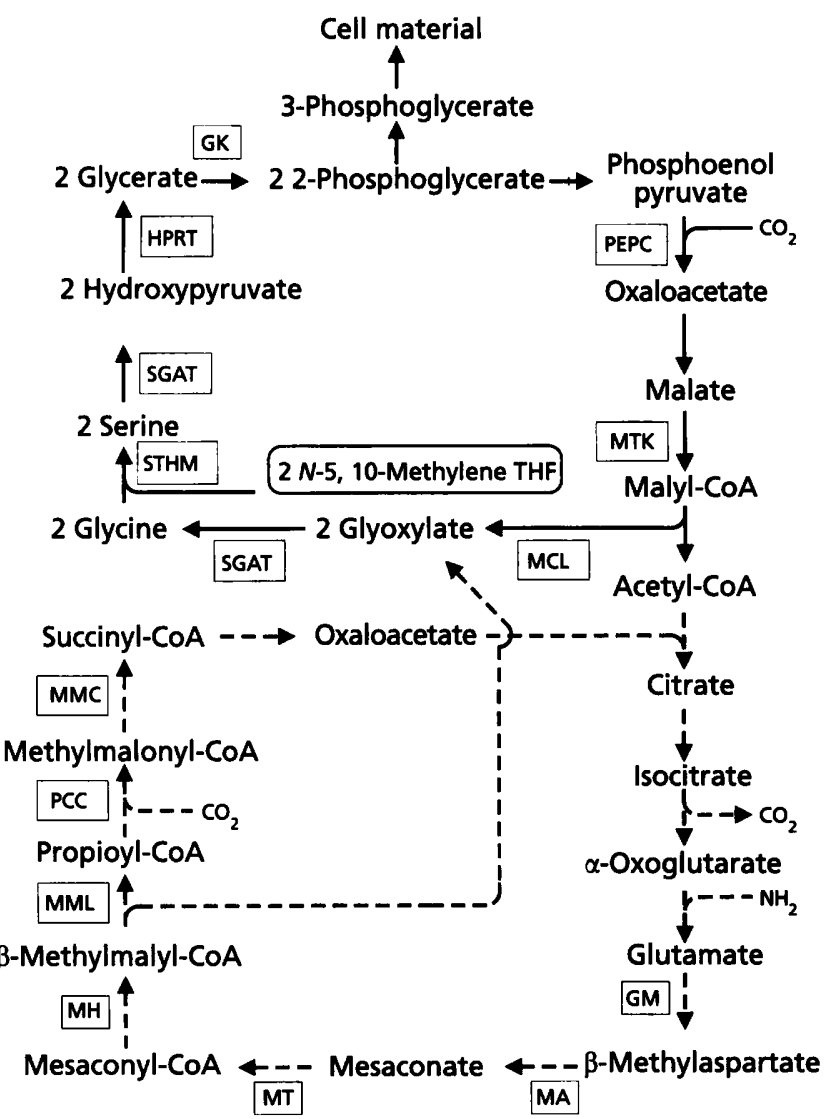

Fig. 1. $|\mathrm{Cl}|^{-}$variant of the serine pathway showing the key enzymes and the route (broken line) for the regeneration of glyoxylate proposed by Shimizu et al. (1984). GK, glycerate kinase; GM, glutamate mutase; HPRT, hydroxypyruvate reductase; MA, $\beta$-methylaspartase; $M C L$, malyl-CoA lyase; $M H_{\text {, }}$ mesaconyl-CoA hydratase; MMC, methylmalonyl-CoA mutase; MML, methylmalyl-CoA lyase; MT, mesaconate thiokinase; MTK, malate thiokinase; PCC, propionyl-CoA carboxylase; PEPC, phosphoenolpyruvate carboxylase; SGAT, serine:glyoxylate aminotransferase; STHM, serine transhydroxymethylase; THF, tetrahydrofolate.

Bolbot \& Anthony, 1980a, b; Stone \& Goodwin, 1989). Mutants with this phenotype are also unable to grow on ethanol and on other substrates assimilated after conversion to acetate, including 1,2-propanediol, $\beta$-hydroxybutyrate and malonate. This suggests that the enzyme(s) defective in these mutants is essential for utilization of these compounds as sole carbon source (Dunstan et al., 1972b; Dunstan \& Anthony, 1973; Bolbot \& Anthony, 1980a, b).

Recently, Chistoserdova \& Lidstrom (1994a) have isolated a mutant defective in serine hydroxymethyltransferase. Surprisingly, it was able to grow on succinate, but not on methanol or ethanol. Furthermore, when the medium was supplemented with glyoxylate it grew on ethanol, but not on methanol. This indicates that serine hydroxymethyltransferase is required for the conversion of acetyl-CoA to glyoxylate, as well as for the fixation of formaldehyde during growth on $\mathrm{C}_{1}$ compounds. The protein encoded by an ORF (orf4) which is found within a cluster of seven other serine pathway genes also has two functions during growth on $\mathrm{C}_{1}$ compounds, one being that it is necessary for the conversion of acetyl-CoA to glyoxylate. The deduced amino acid sequence of this protein does not exhibit similarity with any known proteins (Chistoserdova \& Lidstrom, 1994b).

Three other regions of the $M$. extorquens AM1 chromosome encode serine pathway genes; one complements mutants defective in glycerate kinase and the other two complement mutants which are specifically blocked in the conversion of acetyl-CoA to glyoxylate (Stone \& Goodwin, 1989). In this paper, we describe the isolation and characterization of another mutant of the latter type and demonstrate that it, and two of the previously described mutants, are defective in a protein with similarity with methylmalonyl-CoA mutase.

\section{METHODS}

Bacterial strains. The bacterial strains and plasmids used in this study are listed in Table 1.

Growth of organisms. $M$. extorquens AM1 was grown at $30^{\circ} \mathrm{C}$ on MacLennan's minimal salts medium (MacLennan et al., 1971). Carbon substrates were added to give the following final concentrations: $0.4 \%(\mathrm{v} / \mathrm{v})$ for methanol; $0.5 \%(\mathrm{v} / \mathrm{v})$ for $1,2-$ propanediol; $5 \mathrm{mM}$ for glyoxylate; $0.2 \%(\mathrm{v} / \mathrm{v})$ for ethanol; $0.2 \%(\mathrm{w} / \mathrm{v})$ for other substrates. Eschericbia coli strains were grown in Luria-Bertani broth at $37^{\circ} \mathrm{C}$ (Sambrook et al., 1989). Where appropriate, supplements were added to the medium at the following concentrations: oxytetracycline hydrochloride, $20 \mu \mathrm{g} \mathrm{ml}^{-1}$ for $E$. coli and $12.5 \mu \mathrm{g} \mathrm{m}^{-1}$ for $M$. extorquens AM1; kanamycin sulphate, $50 \mu \mathrm{g} \mathrm{m}^{-1}$ for $E$. coli; ampicillin, $50 \mu \mathrm{g}$ $\mathrm{ml}^{-1} ; \mathrm{X}-\mathrm{Gal}, 20 \mu \mathrm{g} \mathrm{m} \mathrm{m}^{-1}$; isopropyl $\beta$-D-thiogalactoside, $0 \cdot 1 \mathrm{mM}$.

Isolation of mutants. A culture of wild-type M. extorquens AM1 growing on methanol medium was harvested at the midexponential phase of growth and resuspended at a density of approximately $10^{9}$ cells ml-1 in $0.2 \mathrm{M}$ sodium acetate buffer $(\mathrm{pH}$ 6.4) containing $1 \mathrm{mg}$ sodium nitrite $\mathrm{ml}^{-1}$ and $2 \mu \mathrm{g}$ chloramphenicol ml-1, which has been reported to enhance mutagenesis (Mishra \& Tiwari, 1985). After incubation with shaking for $1 \mathrm{~h}$ at $30^{\circ} \mathrm{C}$, the cells were harvested and washed in succinate medium. Expression and penicillin enrichment were done as described by Tatra \& Goodwin (1985). Mutants able to grow on succinate but not on methanol or ethanol were isolated by replica plating.

Preparation of cell extracts and enzyme assays. Cell extracts were prepared as described by Tatra \& Goodwin (1985). Methanol dehydrogenase (EC 1.1.99.8), methylamine dehydrogenase (EC 1.4.99.3) and formaldehyde dehydrogenase (EC 1.2.99.3) were assayed polarographically (Tatra \& Goodwin, 1985; Dawson et al., 1990; Ford et al., 1985). The following enzymes were assayed spectrophotometrically (Shimadzu UV 260 dual beam spectrophotometer) using published methods: formate dehydrogenase (EC 1.2.1.2; Johnson \& Quayle, 1964); hydroxypyruvate reductase (EC 1.1.1.81; Goodwin, 1990); glycerate kinase (EC 2.7.1.31; Goodwin, 1990); serine: glyoxylate aminotransferase (EC 2.6.1.45; Goodwin, 1990); acetyl-CoA independent phosphoenolpyruvate carboxylase (Goodwin, 1990). Malyl-CoA lyase (EC 4.1.3.24) could not be assayed directly because the substrate, malyl-CoA, is not commercially available. The presence of this enzyme was deduced by measuring the apparent malate synthase activity, which is due to the concerted action of malyl-CoA lyase and 
Table 1. Bacterial strains and plasmids

\begin{tabular}{|c|c|c|}
\hline Strain/plasmid & Relevant properties & Source/reference \\
\hline \multicolumn{3}{|l|}{ Bacteria } \\
\hline \multicolumn{3}{|l|}{ M. extorquens AM1 } \\
\hline Wild-type & & Peel \& Quayle (1961) \\
\hline PCT48 & & Dunstan et al. (1972b) \\
\hline PT1005 & Mutants defective in the conversion of acetyl-CoA to glyoxylate & Stone \& Goodwin (1989) \\
\hline LS1 & & This study \\
\hline \multicolumn{3}{|l|}{ E. coli } \\
\hline DSM1607 & $\mathrm{F}^{-}$pro $A 2 \operatorname{rec} A 13 \operatorname{rpsL} 20\left(\mathrm{Str}^{r}\right) b s d S 20(b s d \mathrm{R} b s d M)$ & NCIMB 11865 \\
\hline S17-1 & $\begin{array}{l}\text { thi pro bsdR } \operatorname{rec} A \text {; contains the tra region of RP4 integrated in the } \\
\text { chromosome }\end{array}$ & Simon et al. (1983) \\
\hline CSR603 & $\mathrm{F}^{-} \operatorname{pro} A 2 \operatorname{rec} A 1$ & NCIMB 11867 \\
\hline XL1-Blue & $\begin{array}{l}\text { end } A 1 \text { bsdR } 17\left(\mathrm{r}_{\mathrm{k}}^{-} \mathrm{m}_{\mathrm{k}}^{+}\right) \operatorname{supE} 44 \text { thi-1 rec } A 1(\text { lac }) \mathrm{F}^{\prime} \text { pro } A B \text { lac } I^{\mathrm{q}} Z \Delta \mathrm{M} 15 \\
\operatorname{Tn} 10\left(\mathrm{Tc}^{\mathrm{r}}\right)\end{array}$ & Bullock et al. (1987) \\
\hline P678-54 & $\begin{array}{l}\text { F thr1 ara13 leu-6 azi8 ton A2 lacY1 min } A 1 \text { ginU44 gal6 minB2 rpsL135 } \\
\text { mal } A 1 \text { xyl7 mtl } 2 \text { thi1 }\end{array}$ & Adler et al. (1967) \\
\hline $\mathrm{DH} 5 \alpha$ & 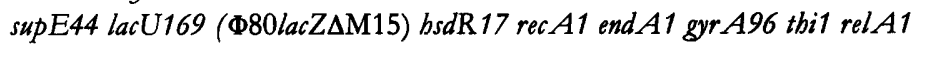 & $\begin{array}{l}\text { Bethesda Research } \\
\text { Laboratories }\end{array}$ \\
\hline \multicolumn{3}{|l|}{ Plasmid/cosmid } \\
\hline pVK100 & IncP1, $\mathrm{Tc}^{\mathrm{r}}, \mathrm{Km}^{\mathrm{r}}$, cos; broad-host-range cloning vector & Knauf \& Nester (1982) \\
\hline pLA2917 & IncP1, $\mathrm{Tc}^{\mathrm{r}}, \mathrm{Km}^{\mathrm{r}}$, cos; broad-host-range cloning vector & Allen \& Hanson (1985) \\
\hline pRK415 & IncP1, $\mathrm{Tc}^{\mathrm{r}}$, lac $Z^{\prime}$; broad-host-range cloning vector & Keen et al. (1988) \\
\hline pRK2013 & $\mathrm{Km}^{\mathrm{r}}$ mobilizing plasmid; ColE1 replicon & Figurski \& Helinski (1979) \\
\hline pBluescriptII KS $(+)$ & $A m p^{r}$ phagemid with ColE1 replicon and $\mathrm{f1}$ phage origins of replication & Stratagene Cloning Systems \\
\hline pTZ18U & $A m p^{r}$ lac $Z^{\prime}$ cloning vector & Bio-Rad \\
\hline pSS48-1, pSS48-2 & $\begin{array}{l}\text { Cosmids isolated from a HindIII clone bank of } M . \text { extorquens AM1 } \\
\text { DNA in pVK100 }\end{array}$ & Stone \& Goodwin (1989) \\
\hline pLS27C & $4.0 \mathrm{~kb}$ EcoRI fragment of pSS48-1 in pRK415 & \\
\hline pLS271C & $1.0 \mathrm{~kb}$ PstI fragment of pLS27C in pLA2917 & \\
\hline pLS273C & $2.2 \mathrm{~kb}$ PstI-EcoRI fragment of $\mathrm{pLS} 27 \mathrm{C}$ in $\mathrm{pRK} 415$ & \\
\hline pLS274C & $1.0 \mathrm{~kb}$ EcoRI-Pst I fragment of $\mathrm{pLS} 27 \mathrm{C}$ in $\mathrm{pRK} 415$ & This ctudy \\
\hline pLS27 & $4.0 \mathrm{~kb}$ EcoRI fragment of pSS48-1 in pBluescript $\mathrm{KS}(+)$ & I his study \\
\hline $\mathrm{pLS} 271$ & $1.0 \mathrm{~kb}$ Pst $\mathrm{I}$ fragment of $\mathrm{pLS} 27$ in pBluescript $\mathrm{KS}(+)$ & \\
\hline pLS272 & $1.2 \mathrm{~kb} E c o \mathrm{RI}-\mathrm{Bg} / \mathrm{II}$ fragment of pLS27 in pBluescript $\mathrm{KS}(+)$ & \\
\hline pLS273 & $2.2 \mathrm{~kb}$ PstI-EcoRI fragment of pLS27 in pTZ18U & \\
\hline
\end{tabular}

malyl-CoA hydrolase (Stone \& Goodwin, 1989). Methylmalonyl-CoA mutase (EC 5.4.99.2) was measured by the method of Zagalak et al. (1974). Enzyme assays were repeated using at least two independent cultures. Protein concentrations were determined by the method of Low ry using BSA fraction V as the standard.

Complementation analysis. Recombinant cosmids were introduced into $M$. extorquens AM1 mutants using either biparental matings (where $E$. coli $\mathrm{S} 17-1$ carrying a recombinant cosmid was the donor) or triparental matings (where other $E$. coli hosts carrying a recombinant cosmid were the donors and the mobilizing plasmid pRK2013 was supplied by E. coli DSM1607). Matings were done using a modification of the method of Fulton et al. (1984). Culture of the recipient $(0 \cdot 1 \mathrm{ml}$; $10^{8}$ cells) was spread onto a nutrient agar plate. The plate was dried and then $20 \mu \mathrm{l}$ culture containing the donor $\left(2 \times 10^{7}\right.$ cells $)$, mixed with an equal number of mobilizer cells if appropriate, was dropped onto the lawn of recipient. After incubation overnight at $30^{\circ} \mathrm{C}$, the plates were replicated onto medium containing (i) succinate plus tetracycline plus carbenicillin (to select for cosmid transfer) and (ii) methanol plus tetracycline (to select for complementation). Carbenicillin $\left(100 \mu \mathrm{g} \mathrm{ml}^{-1}\right)$ was added to the succinate medium to inhibit the growth of $E$. coli which occurred due to carry-over of nutrients from the mating plates. To check that complementation, rather than recombinational rescue, was occurring, single colonies which had been selected for transfer of the cosmid were removed and tested for growth on methanol plus tetracycline. Demonstration that all of these colonies grew on methanol indicated that there was complementation in trans.

Plasmid isolation. A modification of the alkaline lysis method of Birnboim \& Doly (1979) was used for small-scale preparation of plasmid and cosmid DNA (Sambrook et al., 1989). Largescale isolation of plasmid DNA for sequencing was done as described in the Promega Protocols and Applications Guide.

Subcloning. Subcloning and agarose gel electrophoresis were done as described by Sambrook et al. (1989). Enzymes for restriction digestion and DNA manipulations were obtained from Sigma or Northumbria Biologicals and used according to the manufacturers' instructions. A Prep-A-Gene DNA purification kit (Bio-Rad) was used to purify DNA fragments isolated from agarose gels. Recombinant plasmids were introduced into competent $E$. coli cells by transformation as described by Sambrook et al. (1989). 
DNA-DNA hybridization. Chromosomal DNA was isolated from $M$. extorquens AM1 using the method of Fulton et al. (1984). The DNA was digested with an appropriate restriction enzyme and the resulting fragments were separated by agarose gel electrophoresis and then blotted onto a Hybond-N nylon membrane (Amersham), using the Hybaid Vacu-aid according to the manufacturer's instructions.

DNA probes were prepared by random incorporation of digoxigenin-labelled deoxyuridine triphosphate (Boehringer), according to the manufacturer's instructions. Hybridization was done at $68^{\circ} \mathrm{C}$ in a Hybaid incubator as described by Sambrook et al. (1989), using stringent washing conditions, and the hybridized probe was detected using the DIG nucleic acid detection kit (Boehringer).

Nucleotide sequencing. Plasmid pLS27 was digested with Pst I and the resulting $1.0 \mathrm{~kb}$ fragment was cloned into pBluescript $\mathrm{KS}(+)$, generating plasmid pLS271. The $1 \cdot 1 \mathrm{~kb}$ EcoRI-Bg/II fragment of pLS27 was ligated into pBluescript $\mathrm{KS}(+)$ which had been digested with EcoRI and BamHI, giving plasmid pLS272. The $2 \cdot 2 \mathrm{~kb}$ PstI-EcoRI fragment of pLS27 was subcloned into $\mathrm{p} T Z 18 \mathrm{U}$ which had been digested with the same enzymes and a nested set of unidirectional deletions of the resulting plasmid, pLS273, was made. This was done as described by Henikoff (1984), except that mung bean nuclease was used instead of S1 nuclease. DNA fragments were sequenced by the dideoxy chain-termination method (Sanger $e t$ al., 1977). Primers were either obtained commercially or were custom synthesized.

Sequencing was either done with T7 DNA polymerase and $\left.{ }^{35} \mathrm{~S}\right] \mathrm{dATP} \alpha \mathrm{S}$ using the Sequenase kit (US Biochemical) or by using a Pharmacia Automated Laser Fluorescence DNA sequencer.

Sequence data were compiled and analysed using the GCG programs (Devereux et al., 1984) and the programs supplied in the PC/GENE software packages (Intelligenetics).

Preparation and labelling of $E$. coli minicells and analysis of labelled peptides. The E. coli minicell-producing strain P68754 was transformed with pLS27 and with pBluescript $\mathrm{KS}(+)$. Minicells were isolated using a modified version of the method of Clark-Curtiss \& Curtiss (1983) as described by Eggink et al. (1988). The protein products were labelled with [ ${ }^{35}$ S]methionine, analysed by SDS-PAGE and visualized by fluorography (Eggink et al., 1988).

\section{RESULTS AND DISCUSSION}

\section{Isolation and characterization of mutants}

Following nitrous acid mutagenesis, four mutants were isolated which had growth properties typical of mutants unable to convert acetyl-CoA to glyoxylate, i.e. were unable to grow on methanol or ethanol unless the medium was supplemented with glyoxylate. We have designated this phenotype Mea (methanol and $e$ thanol assimilation deficient). Revertants were obtained at a frequency of approximately $10^{-9}$. As expected, the mutants were also unable to utilize methylamine, formate, malonate or $\beta$ hydroxybutyrate as sole carbon source, but could grow on oxalate, which is assimilated by metabolism to glyoxylate and formate and then converted to phosphoglycerate by the appropriate enzymes of the serine pathway (Blackmore \& Quayle, 1970). Surprisingly, pyruvate, lactate and 1,2propanediol, which are also thought to be assimilated by a route involving metabolism to acetyl-CoA and its subsequent conversion to glyoxylate (Salem et al., 1973b; Bolbot \& Anthony, 1980a, b), supported growth of the new isolates and also of two previously described mutants, PCT48 and PT1005. However, all of the mutants grew much more slowly than the wild-type on 1,2-propanediol and this may account for the failure of Bolbot \& Anthony (1980b) to observe growth of PCT48 on this substrate. These results suggest that, if acetate is an intermediate in the assimilation of pyruvate, lactate and 1,2-propanediol, it must be metabolized by a route which does not involve conversion to glyoxylate.

Biochemical and complementation analysis indicated that the four new mutants were identical so the results for only one-LS1 - are given. It was grown on medium containing succinate plus methanol plus methylamine, harvested, and incubated overnight in medium containing methanol plus methylamine to induce the $\mathrm{C}_{1}$-metabolizing enzymes. Crude extracts were then assayed for the known key enzymes of the serine pathway. Serine:glyoxylate aminotransferase, hydroxypyruvate reductase, glycerate kinase and the acetyl-CoA-independent phosphoenolpyruvate carboxylase were all detected, as were the $C_{1}$ oxidizing enzymes methanol dehydrogenase, methylamine dehydrogenase, formaldehyde dehydrogenase and formate dehydrogenase. The presence of malyl-CoA lyase was deduced by demonstrating an apparent malate synthase activity, which is due to the concerted action of malyl-CoA lyase and malyl-CoA hydrolase. We did not assay for serine hydroxymethyltransferase, but this enzyme must be present since LS1 grew on oxalate and on methanol in the presence of glyoxylate.

\section{Complementation analysis}

Stone \& Goodwin (1989) isolated two overlapping cosmids (pSS48-1 and pSS48-2) from a HindIII genomic library of $M$. extorquens AM1 DNA constructed in the broad-host-range mobilizable cosmid pVK100, and demonstrated that they complemented two mutants, PCT48 and PT1005, which were unable to convert acetyl-CoA to glyoxylate; a third mutant with the same phenotype (Cou4) was not complemented. pSS48-1 and pSS48-2 also complemented mutant LS1.

pLS27C, a subclone of pSS48-1 which contained a $4.0 \mathrm{~kb}$ EcoRI fragment of pSS48-1, also complemented all of the mutants but subclones containing smaller DNA fragments derived from pLS27C did not (Fig. 2). However, when one of these (pLS274C) was introduced into PT1005, approximately $1 \%$ of the transconjugants which had received the cosmid grew on methanol, indicating that recombinational rescue had occurred. Recombinational rescue also occurred when pLS273C was introduced into LS1.

\section{Mutant PCT48 contains a chromosomal deletion}

In common with Dunstan $e$ t al. (1972b), we were unable to isolate revertants of this mutant and we therefore investigated their suggestion that PCT48 is a deletion 
(a)

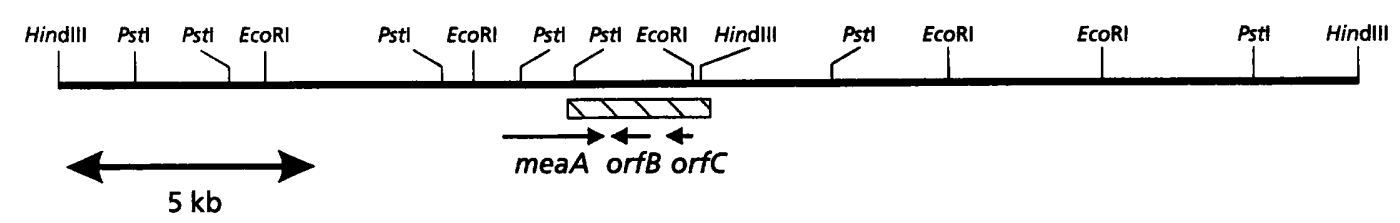

(b)

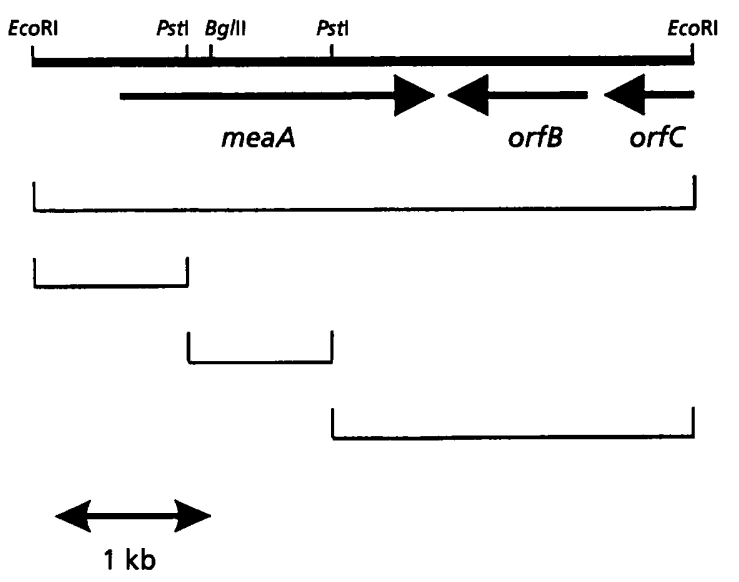

\begin{tabular}{cccc}
\hline & \multicolumn{4}{c}{ M. extorquens strain } \\
Plasmid & PCT48 & PT1005 & LS1 \\
\hline pLS27C & C & C & C \\
pLS274C & - & R & - \\
pLS271C & - & - & - \\
pLS273C & - & - & R \\
\hline
\end{tabular}

Fig. 2. (a) Restriction map of the $26 \mathrm{~kb}$ HindlII insert of cosmid pSS48-1. The hatched box indicates the position of the deletion in PCT48. (b) Complementation analysis of the Mea mutants using subclones of pSS48-1. C, Complementation; $R$, recombination; -, no complementation or recombination. The positions and directions of transcription of meaA, orf $B$ and orfC are indicated by arrows.

(a)

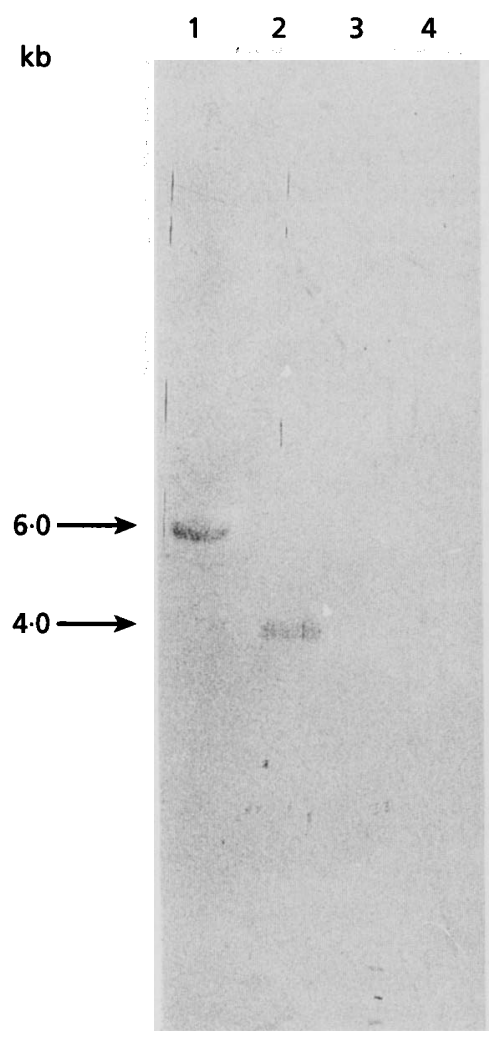

(b)

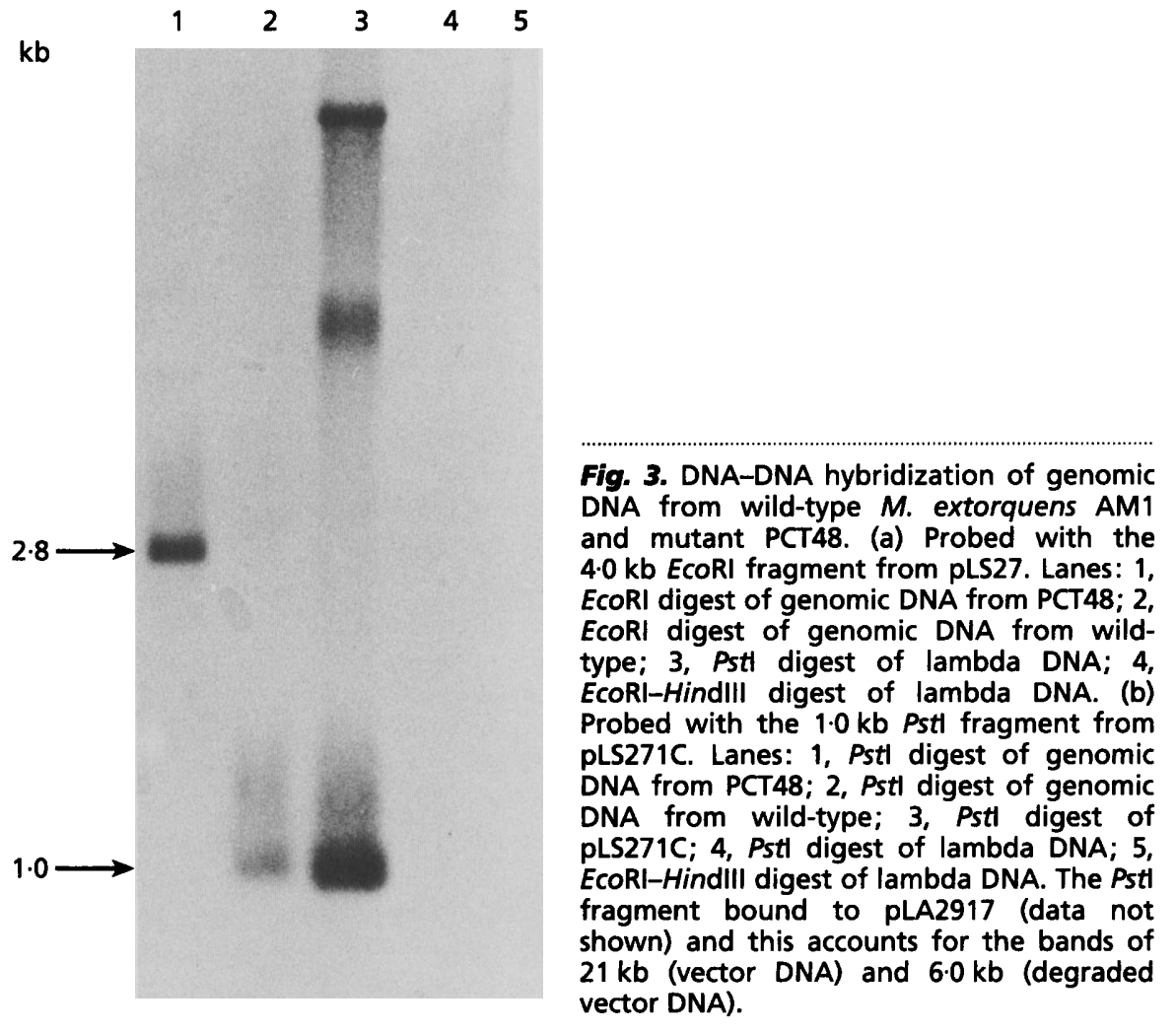




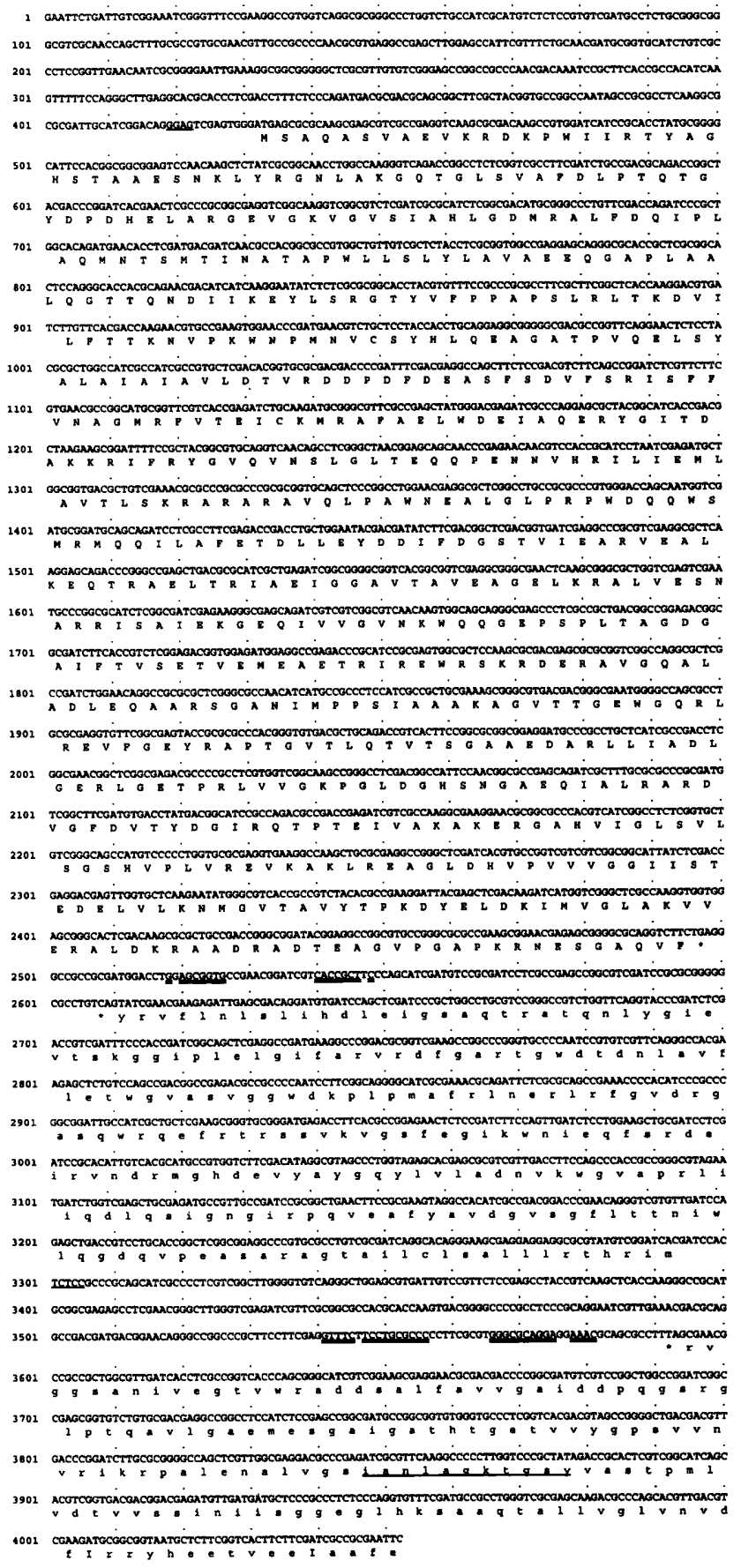

Fig. 4. Nucleotide sequence of the $M$. extorquens AM1 chromosomal region containing meaA, orfB and the 3 '-terminus of orfC. Amino acids are represented by the single letter code. The conceptual translation of orfB and orfC is from the reverse complement (lower-case letters). Putative ribosome-binding sites are underlined, putative transcriptional terminator sequences are double underlined and asterisks indicate stop codons. The underlined amino acid sequence represents the short-chain alcohol dehydrogenase family signature.

mutant. Chromosomal DNA isolated from the wild-type strain and from PCT48 was digested with EcoRI. The resulting fragments were separated by gel electrophoresis and probed with the $4.0 \mathrm{~kb}$ EcoRI fragment which complemented all of the mutants. It hybridized to a $4.0 \mathrm{~kb}$ fragment of wild-type DNA, as expected; in contrast, it hybridized to a DNA fragment of about $6 \mathrm{~kb}$ from PCT48 (Fig. 3a). Thus, there must be a deletion in the chromosome of PCT48 involving one of the EcoRI sites of the DNA fragment cloned in pLS27C.

The genomic DNA from the two strains was also digested with Pst I and probed with the $1.0 \mathrm{~kb}$ Pst I fragment derived from pLS27C. As expected, it hybridized to a $1.0 \mathrm{~kb}$ DNA fragment from the wild-type; however, it hybridized to a $2.8 \mathrm{~kb}$ fragment from the mutant DNA (Fig. 3b). In view of the positions of the PstI and EcoRI restriction sites on pSS48-1, the chromosome of PCT48 must contain a deletion of $2.7 \mathrm{~kb}$, which covers the $2.2 \mathrm{~kb}$ EcoRI-PstI fragment (Fig. 2). The complementation analysis indicated that the $2 \cdot 2 \mathrm{~kb} E c o \mathrm{RI}-P s t \mathrm{I}$ fragment of pLS27C was essential for growth on methanol and ethanol.

\section{The mea locus contains a gene encoding a protein which has similarity with methylmalonyl-CoA mutase}

The nucleotide sequence of the $4.0 \mathrm{~kb}$ EcoRI fragment cloned in pLS27 is shown in Fig. 4. It contained one large ORF with two possible initiation codons and translation from these putative start codons would give rise to proteins of 78 and $75 \mathrm{kDa}$. Only the second ORF has a typical ribosome-binding site upstream. Complementation analysis showed that this gene was defective in the Mea mutants PT1005 and LS1, indicating that it is essential for the conversion of acetyl-CoA to glyoxylate; we have therefore called it mea $A$. A smaller ORF of $687 \mathrm{bp}($ orf $B$ ) was present $118 \mathrm{bp}$ downstream from mea $A$ and was transcribed in the opposite direction. The $3^{\prime}$-end of a third ORF (orfC) was identified $297 \mathrm{bp}$ from orf $B$. Both the intergenic regions contained inverted repeats which resembled tho-independent termination sequences (Platt, 1986). The deletion in PCT48 extends into orfC and, since this mutant was complemented by the $4.0 \mathrm{~kb}$ EcoRI fragment which does not contain the complete orfC gene, this gene cannot be considered essential for growth on methanol.

The predicted amino acid sequences of the ORFs were compared with entries in the protein database at the National Center for Biotechnology Information (NCBI) using the program BLAST (Altschul et al., 1990). The mea $A$ gene product had a high degree of similarity with the methylmalonyl-CoA mutases, which are adenosylcobalamin-dependent enzymes catalysing the interconversion of methylmalonyl-CoA and succinyl-CoA (Fig. 5). The enzymes from Propionibacterium shermanii, Streptomyces cinnamonensis and Porpbyromonas gingivalis are heterodimers consisting of a large subunit (approximately $79 \mathrm{kDa}$ ) and a small subunit (approximately $65 \mathrm{kDa}$ ) (Marsh et al., 1989; Birch et al., 1993). In contrast, the mouse and human enzymes comprise two identical subunits of $82 \mathrm{kDa}$ (Ledley et al., 1988; Jansen et al., 1989; Wilkemeyer et al., 1990). The $s b m$ gene of E. coli encodes 


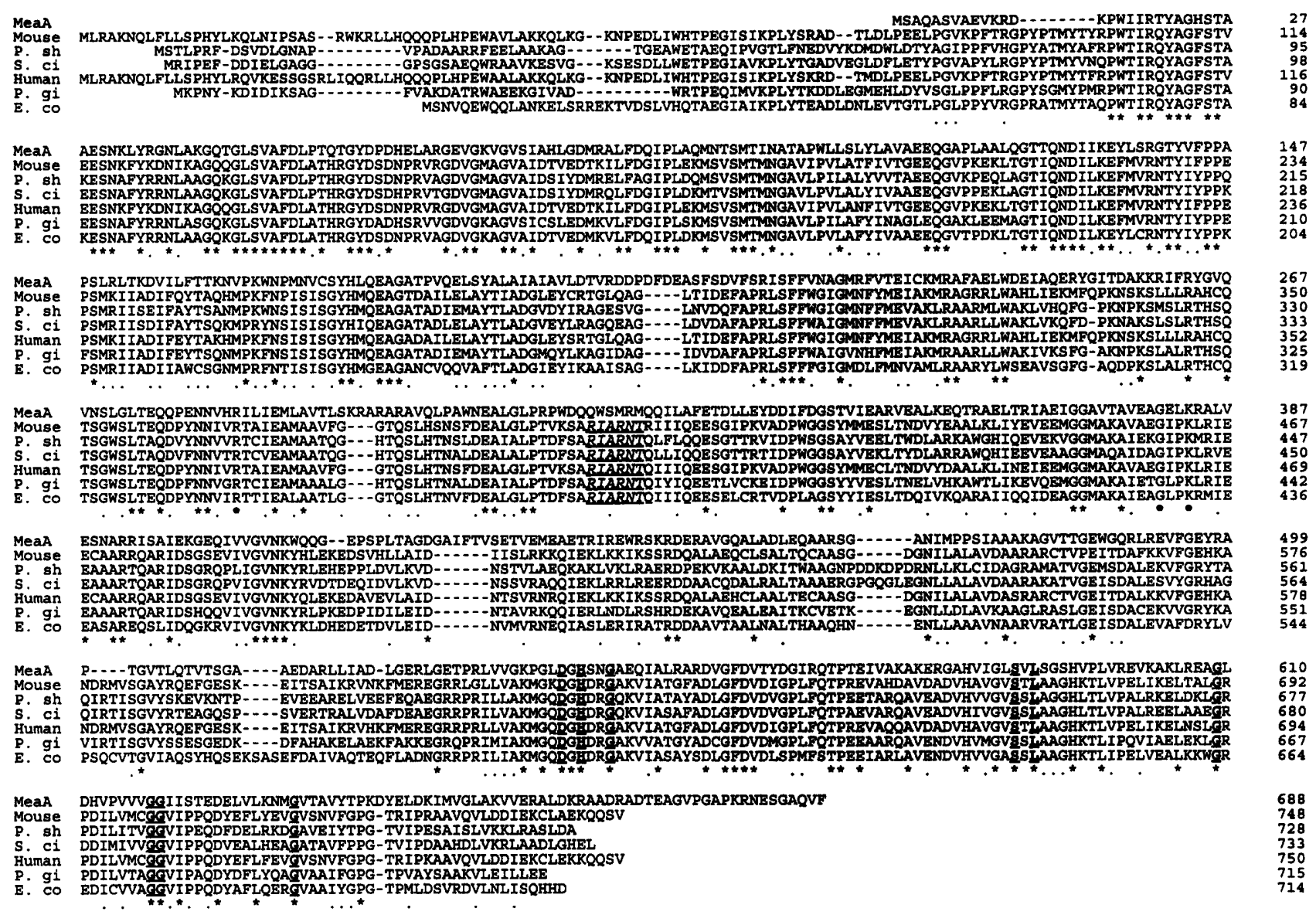

Fig. 5. Alignment of the deduced amino acid sequence of MeaA with sequences of members of the methylmalonyl-CoA mutase family from other sources. P. sh, Prop. shermanii large subunit; S. ci, S. cinnamonensis large subunit; P. gi, Porp. gingivalis large subunit; $E$. co; $E$. coli $s b m$ gene product. Identical residues are indicated by an asterisk, and conserved substitutions, according to the scheme PAGST, QNED, ILVM, HKR, YFW, C, are indicated by a dot. Numbers refer to nucleotide residues. The amino acid residues shown in bold and underlined represent the proposed vitamin- $B_{12}-b^{-}$inding site and those in italics and underlined represent the conserved sequence in all methylmalonyl-CoA mutases.

a polypeptide of $78 \mathrm{kDa}$ which also belongs to this family of proteins (Roy \& Leadlay, 1992). Individual sequence alignments indicated that MeaA has $56-57 \%$ similarity with the large subunits of the bacterial enzymes, the mouse and human enzymes and the sbm gene product. The identities were $37-37.5 \%$ in the case of the $S$. cinnamonensis and Porp. gingivalis large subunits and the sbm gene product, and $34 \%$ with the mouse, human and Prop. shermanii large subunits. In contrast, there was only about $46 \%$ similarity and $24 \%$ identity with the small subunits of the bacterial enzymes.

Three short, highly conserved regions are present in a number of cobalamin-dependent enzymes and it has been proposed that they are involved in cobalamin binding (Marsh \& Holloway, 1992; Crane et al., 1992; Drennan et al., 1994). These sequences (DXHXXG, SXL and $\mathrm{GX}_{8} \mathrm{GGX}_{14} \mathrm{G}$ ) also occur in MeaA (Fig. 5). There is another highly conserved sequence (RIARNT) in all of the methylmalonyl-CoA mutases sequenced thus far, but this is not present in mea $A$ (Fig. 5).
The deduced amino acid sequence of the polypeptide encoded by $\operatorname{orf} B$ did not have significant sequence similarity with any known protein. The predicted amino acid sequence encoded by the partial ORF of orfC had homology with the 3-oxoacyl-[acyl-carrier-protein] reductases of Brassica napus (63\% similarity, $41.5 \%$ identity), Arabidopsis thaliana (64\% similarity, $39 \%$ identity) (Slabas et al., 1992) and E. coli (62\% similarity, $37 \%$ identity) (Cronan \& Rawlings, 1992). This enzyme, which is a member of the short-chain alcohol dehydrogenase family, catalyses the first reduction step in fatty acid biosynthesis.

\section{Translation products of $m e a A$}

The $4.0 \mathrm{~kb}$ fragment cloned in pLS27 was expressed in $E$. coli minicells and the resulting products were analysed using denaturing $8 \%$ and $12.5 \%(\mathrm{w} / \mathrm{v})$ SDS-polyacrylamide gels, which together would have resolved both the polypeptides predicted to be expressed from this fragment. Three polypeptides, with apparent molecular 


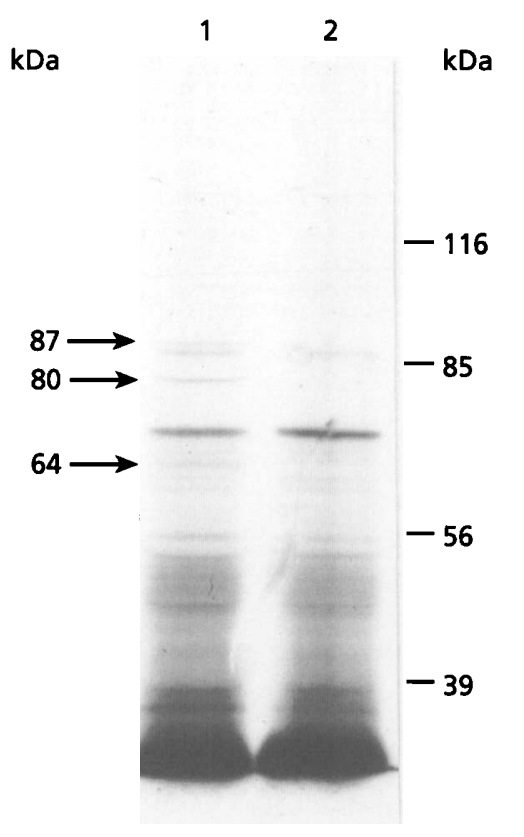

Fig. 6. SDS-polyacrylamide gel ( $8 \%)$ showing polypeptides synthesized by $E$. coli minicells containing a recombinant plasmid with the $4.0 \mathrm{~kb}$ ECORI insert of pLS27 (lane 1) cloned in pBluescript. The molecular masses of marker polypeptides are shown on the right-hand side. The arrows on the left-hand side indicate polypeptides which are synthesized by the recombinant plasmid, but not the control, pBlue (lane 2).

masses of 87,80 and $64 \mathrm{kDa}$, were present in minicells expressing this fragment, but not in controls (Fig. 6). The first is somewhat larger than the size of the predicted gene product of mea $A$, but estimates of polypeptide size from SDS-PAGE are often inaccurate. Degradation of large proteins often occurs in minicell expression systems (Eggink et al., 1988) and this presumably accounts for the presence of the 80 and $64 \mathrm{kDa}$ polypeptides. We did not observe any small polypeptides of the size expected of the orf $B$ gene product, which is predicted to be $25.5 \mathrm{kDa}$.

\section{Mutant PCT48 has methylmalonyl-CoA mutase activity}

Methylmalonyl-CoA mutase was assayed in cell extracts of the wild-type and mutant PCT48 grown and induced as described in Methods. The specific activity of this enzyme was similar in the wild-type and in mutant PCT48 which contains a deletion in mea $A$, the value being $280 \mathrm{nmol}$ $\min ^{-1}(\mathrm{mg} \text { protein })^{-1} \pm 15 \%$. This does not preclude the possibility that mea $A$ encodes an isoenzyme of methylmalonyl-CoA mutase which is required specifically for growth on methanol, although if this is the case it is surprising that the specific activities in the mutant and wild-type are similar. The role of the highly conserved sequence present in all of the methylmalonyl-CoA mutases but not in MeaA is unknown, but it presumably has functional significance. Thus the possibility that mea $A$ codes for a novel cobalamin-binding protein needs to explored.
Our results support the suggestion made by Shimizu et al. (1984) that vitamin- $B_{12}$-dependent enzymes are involved in the assimilation of methanol and ethanol. These authors proposed that two adenosylcobalamin-dependent enzymes, methylmalonyl-CoA mutase and glutamate mutase, were required for the conversion of acetyl-CoA to glyoxylate and that $\beta$-methylaspartate, mesaconyl-CoA, $\beta$ methylmalyl-CoA, propionyl-CoA and methylmalonylCoA were intermediates (Fig. 1). It is unlikely that this pathway is correct since serine hydroxymethyltransferase and an ORF encoding a polypeptide of unknown function are essential for the conversion of acetyl-CoA to glyoxylate (Chistoserdova \& Lidstrom, 1994a, b), although the possibility that these proteins are required to generate an inducer of the genes involved in this part of the serine pathway cannot be excluded. We have now shown that the MeaA protein is also needed, and further work is underway to determine whether it is a mutase with an unusual substrate specificity or whether it has some other function.

\section{ACKNOWLEDGEMENTS}

We thank the SERC for a PhD studentship to L.S. and NESCOT for providing facilities and assistance for this work. We are also very grateful to Dr Peter Leadlay, Cambridge, for advice on the methylmalonyl-CoA mutase assay and for the gift of coupling enzymes for the assay; and to Dr Chris Thurston, King's College London, for providing advice and facilities for some of the sequencing work.

\section{REFERENCES}

Adler, H. I., Fisher, W. D., Cohen, A. \& Hardigree, A. A. (1967). Minature Escherichia coli cells deficient in DNA. Proc Natl Acad Sci US A 57, 321-326.

Allen, L. N. \& Hanson, R. S. (1985). Construction of broad host range cosmid cloning vectors: identification of genes necessary for growth of Metbylobacterium organophilum on methanol. $J$ Bacteriol 161, 955-962.

Altschul, S. F., Gish, W., Miller, W., Myers, E. W. \& Lipman, D. J. (1990). Basic local alignment search tool. J Mol Biol 215, 403-410.

Anthony, C. (1982). The Biochemistry of Metbylotrophs. London: Academic Press.

Bellion, E. \& Hersh, L. B. (1972). Methylamine metabolism in a Pseudomonas species. Arch Biochem Biophys 153, 368-374.

Birch, A., Leiser, A. \& Robinson, J. A. (1993). Cloning, sequencing and expression of the gene encoding methylmalonyl CoA mutase from Streptomyces cinnamonensis. J Bacteriol 175, 3511-3519.

Birnboim, H. C. \& Doly, J. (1979). A rapid alkaline extraction procedure for screening recombinant plasmid DNA. Nucleic Acids Res 7, 1513-1523.

Blackmore, M. A. \& Quayle, J. R. (1970). Microbial growth on oxalate by a route not involving glyoxylate carboligase. Biochem $J$ 118, 53-59.

Bolbot, J. A. \& Anthony, C. (1980a). The metabolism of pyruvate by the facultative methylotroph Pseudomonas AM1.J Gen Microbiol 120, 233-244.

Bolbot, J. A. \& Anthony, C. (1980b). The metabolism of 1,2propanediol by the facultative methylotroph Pseudomonas AM1. $J$ Gen Microbiol 120, 245-254. 
Bullock, W. O., Fernandez, J. M. \& Short, J. M. (1987). XL-1 Blue: a high efficiency plasmid transforming recA Escherichia coli strain with $\beta$-galactosidase selection. BioTechniques 5, 376-379.

Chistoserdova, L. V. \& Lidstrom, M. E. (1994a). Genetics of the serine cycle in Metbylobacterium extorquens AM1 : cloning, sequence, mutation and physiological effect of $g l y A$, the gene for serine hydroxymethyltransferase. $J$ Bacteriol 176, 6759-6763.

Chistoserdova, L. V. \& Lidstrom, M. E. (1994b). Genetics of the serine cycle in Metbylobacterium extorquens AM1: identification, sequence and mutation of three new genes involved in $C_{1}$ assimilation, orf4, $m t k A$ and $m t k B$. $J$ Bacteriol 176, 7398-7404.

Clark-Curtiss, J. E. \& Curtiss, E. I. (1983). Analysis of recombinant DNA using Escherichia coli minicells. Methods Enyymol 101, 347-362.

Crane, A. M., Jansen, R., Andrews, E. R. \& Ledley, F. D. (1992). Cloning and expression of a mutant methylmalonyl CoA mutase with altered cobalamin affinity that causes mut-methylmalonic aciduria. J Clin Invest 89, 385-391.

Cronan, J. E. \& Rawlings, M. (1992). The gene encoding Escherichia coli acyl carrier protein lies within a cluster of fatty acid biosynthesis genes. J Biol Chem 267, 5751-5754.

Dawson, A., Southgate, G. \& Goodwin, P. M. (1990). Regulation of methanol and methylamine dehydrogenases in Metbylophilus methylotrophus. FEMS Microbiol Lett 68, 93-96.

Devereux, J., Haeberli, P. \& Smithies, O. (1984). A comprehensive set of sequence analysis programs for the VAX. Nucleic Acids Res 12, 387-395

Drennan, C. L., Matthews, R. G. \& Ludwig, M. L. (1994). Cobalamin-dependent methionine synthase: the structure of a methylcobalamin-binding fragment and implications for other $\mathrm{B}_{12^{-}}$ dependent enzymes. Curr Opin Struct Biol 4, 919-929.

Dunstan, P. M. \& Anthony, C. (1973). Microbial metabolism of $C_{1}$ and $\mathrm{C}_{2}$ compounds. The role of acetate during growth of Pseudomonas AM1 on $\mathrm{C}_{1}$ compounds, ethanol and $\beta$-hydroxybutyrate. Biochem J 132, 797-801.

Dunstan, P. M., Anthony, C \& Drabble, W. T. (1972a). Microbial metabolism of $C_{1}$ and $C_{2}$ compounds: the involvement of glycollate in the metabolism of ethanol and of acetate by Pseudomonas AM1. Biochem J 128, 99-106.

Dunstan, P. M., Anthony, C. \& Drabble, W. T. (1972b). Microbial metabolism of $C_{1}$ and $C_{2}$ compounds: the role of glyoxylate, glycollate and acetate in the growth of Pseudomonas AM1 on ethanol and on $\mathrm{C}_{1}$ compounds. Biochem J 128, 107-115.

Eggink, G., Engel, H., Meijer, W. G., Otten, J., Kingma, J. \& Witholt, B. (1988). Alkane utilisation in Pseudomonas oleovorans. J Biol Chem 263, 13400-13405.

Figurski, D. H. \& Helinski, D. R. (1979). Replication of an origin containing derivative of plasmid RK2 dependent on a plasmid function provided in trans. Proc Natl Acad Sci US A 76, 1648-1652.

Ford, S., Page, M. D. \& Anthony, C. (1985). The role of a methanol dehydrogenase modifier protein and aldehyde dehydrogenase in the growth of Pseudomonas AM1 on 1,2-propanediol. J Gen Microbiol 131, 2173-2182.

Fulton, G. L., Nunn, D. N. \& Lidstrom, M. E. (1984). Molecular cloning of a malyl CoA lyase gene from Pseudomonas sp. strain AM1, a facultative methylotroph. $J$ Bacteriol 160, 718-723.

Goodwin, P. M. (1990). Assay of assimilatory enzymes in crude extracts of some serine pathway methylotrophs. Methods Enzymol 188, 361-365.

Henikoff, S. (1984). Unidirectional digestion with exonuclease III creates targeted breakpoints for DNA sequencing. Gene 28, 351-359.
Jansen, R., Kalousek, F., Fenton, W. A., Rosenberg, L. E. \& Ledley, F. D. (1989). Cloning of full length methylmalonyl-CoA mutase from a cDNA library using the polymerase chain reaction. Genomics 4, 198-205.

Johnson, P. A. \& Quayle, J. R. (1964). Microbial growth on $C_{1}$ compounds. 6. Oxidation of methanol, formaldehyde and formate by methanol grown Pseudomonas AM1. Biocbem J 93, 281-290.

Keen, N. T., Tamaki, S., Kobayashi, D. \& Trollinger, D. (1988). Improved broad-host-range plasmids for DNA cloning in Gram negative bacteria. Gene 70, 191-197.

Knauf, V. C. \& Nester, E. W. (1982). Wide host range cloning vectors: a cosmid clone bank of an Agrobacterium Ti plasmid Plasmid 8, 45-54.

Kortstee, G. J. J. (1981). The second part of the $\mathrm{icl}^{-}$serine pathway. In Microbial Growth on $C_{1}$ Compounds, pp. 211-219. Edited by $\mathrm{H}$. Dalton. London: Heyden \& Son.

Ledley, F. D., Lumetta, M., Nguyen, P. N., Kohlhouse, J. F. \& Allen, R. H. (1988). Molecular cloning of L-methylmalonyl-CoA mutase: gene transfer and analysis of mut cell lines. Proc Natl Acad Sci US A 85, 3518-3521.

MacLennan, D. G., Ousby, J. C., Vasey, R. B. \& Cotton, N. T. (1971). The influence of dissolved oxygen on Pseudomonas AM1 grown on methanol in continuous culture. J Gen Microbiol 69, 395-404.

Marsh, E. N. G. \& Holloway, D. E. (1992). Cloning and sequencing of glutamate mutase component $\mathrm{S}$ from Clostridium tetanomorphum: homologies with other cobalamin-dependent enzymes. FEBS Lett 310, 167-170.

Marsh, E. N., Mckie, N., Davis, N. K. \& Leadlay, P. F. (1989). Cloning and structural characterization of the genes coding for adenosylcobalamin-dependent methylmalonyl CoA mutase from Propionibacterium shermanii. Biochem J 260, 345-352.

Mishra, A. K. \& Tiwari, D. N. (1985). Enhancement of NTG mutagenesis by chloramphenicol in Gloeotrichia ghosei. Mol $\mathcal{E}$ Gen Genet 201, 351-352.

Peel, D. \& Quayle, J. R. (1961). Microbial growth on $C_{1}$ compounds. 1. Isolation and characterisation of Pseudomonas AM1. Biochem J 81, 465-469.

Platt, T. (1986). Transcriptional termination and the regulation of gene expression. Annu Rev Biochem 55, 339-372.

Roy, I. \& Leadlay, P. F. (1992). Physical map location of the new Escherichia coli gene sbm. J Bacteriol 174, 5763-5764.

Salem, A. R., Hacking, A. J. \& Quayle, J. R. (1973a). Cleavage of malyl-Coenzyme A into acetyl Coenzyme A and glyoxylate by Pseudomonas AM1 and other $\mathrm{C}_{\mathbf{1}}$-unit-utilizing bacteria. Biochem $J$ 136, 89-96.

Salem, A. R., Wagner, C., Hacking, A. J. \& Quayle, J. R. (1973b). The metabolism of lactate and pyruvate by Pseudomonas AM1.J Gen Microbiol 76, 375-388.

Salem, A. R., Hacking, A. J. \& Quayle, J. R. (1974). Lack of malylCoA lyase in a mutant of Pseudomonas AM1. J Gen Microbiol 81, 525-527.

Sambrook, J., Fritsch, E. F. \& Maniatis, T. (1989). Molecular Cloning: a Laboratory Manual, 2nd edn. Cold Spring Harbor, NY: Cold Spring Harbor Laboratory.

Sanger, F., Nicklen, S. \& Coulson, A. R. (1977). DNA sequencing with chain-terminating inhibitors. Proc Natl Acad Sci USA 74, 5463-5467.

Shimizu, S., Ueda, S. \& Sato, K. (1984). Physiological role of vitamin $B_{12}$ in a methanol utilising bacterium, Protaminobacter ruber. In Microbial Growth on $C_{1}$ Compounds, pp. 113-117. Edited by R. L. 
Crawford \& R. S. Hanson. Washington, DC: American Society for Microbiology.

Simon, R., Priefer, U. \& Puhler, A. (1983). A broad host range mobilisation system for in vivo genetic engineering; transposon mutagenesis in Gram negative bacteria. Biotechnology 1, 784-791.

Slabas, A. R., Chase, D., Nishida, I., Murata, N., Sidebottom, C., Safford, R., Sheldon, P. S., Kekwick, R. G., Hardie, D. G. \& Mackintosh, R. W. (1992). Molecular cloning of higher plant 3oxoacyl-(acyl carrier protein) reductase. Sequence identities with the nodG gene product of the nitrogen fixing soil bacterium Rbizobium meliloti. Biochem J 283, 321-326.

Stone, S. \& Goodwin, P. M. (1989). Characterization and complementation of mutants of Metbylobacterium AM1 which are defective in $C_{1}$ assimilation. J Gen Microbiol 135, 227-235.
Tatra, P. K. \& Goodwin, P. M. (1985). Mapping of some genes involved in $\mathrm{C}_{1}$ metabolism in the facultative methylotroph Metbylobacterium sp. strain AM1 (Pseudomonas AM1). Arch Microbiol 143, 169-177.

Wilkemeyer, M. F., Crane, A. M. \& Ledley, F. D. (1990). Primary structure and activity of mouse methylmalonyl CoA mutase. Biochem J 271, 449-455.

Zagalak, B., Retey, J. \& Sund, H. (1974). Studies on methylmalonyl CoA mutase from Propionibacterium shermanii. Eur J Biochem 44, 529-534.

Received 15 August 1995; revised 24 October 1995; accepted 7 November 1995. 